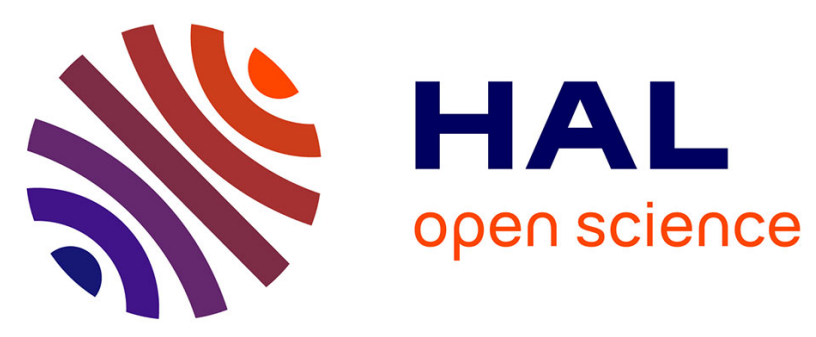

\title{
Regiocontrolled palladium-catalyzed direct C2-arylations of Methoxalen using benzenesulfonyl chlorides and C2,C3-diarylations using aryl bromides as the aryl sources
}

\author{
H. Li, T. Roisnel, Jean-François Soulé, H. Doucet
}

\section{To cite this version:}

H. Li, T. Roisnel, Jean-François Soulé, H. Doucet. Regiocontrolled palladium-catalyzed direct C2arylations of Methoxalen using benzenesulfonyl chlorides and C2,C3-diarylations using aryl bromides as the aryl sources. Tetrahedron Letters, 2020, 61 (1), pp.151342. 10.1016/j.tetlet.2019.151342 . hal-02443572

\author{
HAL Id: hal-02443572 \\ https://hal.science/hal-02443572
}

Submitted on 11 Feb 2020

HAL is a multi-disciplinary open access archive for the deposit and dissemination of scientific research documents, whether they are published or not. The documents may come from teaching and research institutions in France or abroad, or from public or private research centers.
L'archive ouverte pluridisciplinaire HAL, est destinée au dépôt et à la diffusion de documents scientifiques de niveau recherche, publiés ou non, émanant des établissements d'enseignement et de recherche français ou étrangers, des laboratoires publics ou privés. 


\section{Graphical Abstract}

To create your abstract, type over the instructions in the template box below.

Fonts or abstract dimensions should not be changed or altered.

Regiocontrolled palladium-catalyzed direct $\mathrm{C} 2$ arylations of Methoxalen using benzenesulfonyl chlorides and C2,C3-diarylations using aryl bromides as the aryl sources

Haoran $\mathrm{Li}^{\mathrm{a}}$, Thierry Roisnel ${ }^{\mathrm{a}}$, Jean-François Soule ${ }^{\mathrm{a}}{ } *$ and Henri Doucet ${ }^{\mathrm{a}}{ }^{*}$

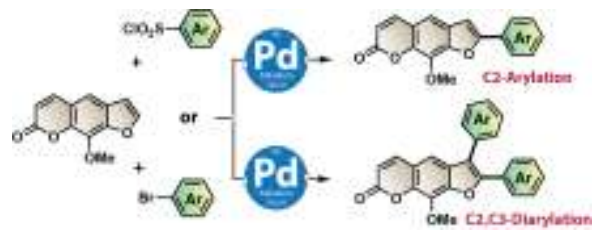




\title{
Regiocontrolled palladium-catalyzed direct C2-arylations of Methoxalen using benzenesulfonyl chlorides and C2,C3-diarylations using aryl bromides as the aryl sources
}

\author{
Haoran $\mathrm{Li}^{\mathrm{a}}$, Thierry Roisnel ${ }^{\mathrm{a}}$, Jean-François Soule ${ }^{\mathrm{a}}{ }{ }$ and Henri Doucet ${ }^{\mathrm{a}}{ }$ * \\ ${ }^{a}$ Univ Rennes, CNRS, ISCR-UMR 6226, F-35000 Rennes, France.
}

\section{ARTICLE INFO}

\section{ABSTRACT}

Article history:

Received

Received in revised form

Accepted

Available online

\section{Keywords:}

Homogeneous catalysis

Palladium

C-H bond functionalization

Methoxalen
Conditions for the regioselective palladium-catalyzed direct C2-arylation and C2,C3-diarylation of Methoxalen are described. The use of benzenesulfonyl chlorides as the coupling partner allowed control of the regioselectivity of the arylation in favor of the $\mathrm{C} 2$ carbon of Methoxalen. This method tolerates a variety of substituents on the benzenesulfonyl chloride derivative. Notably, 2-, 3-, and 4-bromobenzenesulfonyl chlorides and 4-iodobenzenesulfonyl chloride were coupled with Methoxalen without cleavage of the $\mathrm{C}-\mathrm{Br}$ or C-I bonds. Conversely, the use of an excess amount of aryl bromides as the aryl source provides access to C2,C3-diarlyated Methoxalenes.

2019 Elsevier Ltd. All rights reserved.

\section{Introduction}

Among polycyclic heteroarenes, the linear furanocoumarin $7 H$-furo[3,2-g]chromen-7-one (or Psoralen) unit can be found in several drugs and natural products (Fig. 1). For example, Methoxalen (also called Xanthotoxin) and Bergapten are drugs employed in the treatment of psoriasis, eczema, vitiligo, and some cutaneous lymphomas. Trioxsalen is also used for the phototherapy treatment of vitiligo and hand eczema.

Since the seminal work by Ohta and co-workers in 1985 on the Pd-catalyzed arylation of several heteroaromatics, including furans, with aryl halides via $\mathrm{C}-\mathrm{H}$ bond activation, ${ }^{1}$ the so-called direct arylation of heteroaryl derivatives has been demonstrated to be an extremely powerful pathway to access arylated heterocycles. ${ }^{2}$ When this methodology can be applied to the latestage functionalization of drugs, it provides an appealing method to build a library of compounds allowing the easy screening of the biological properties of compounds containing a specific bioactive unit.

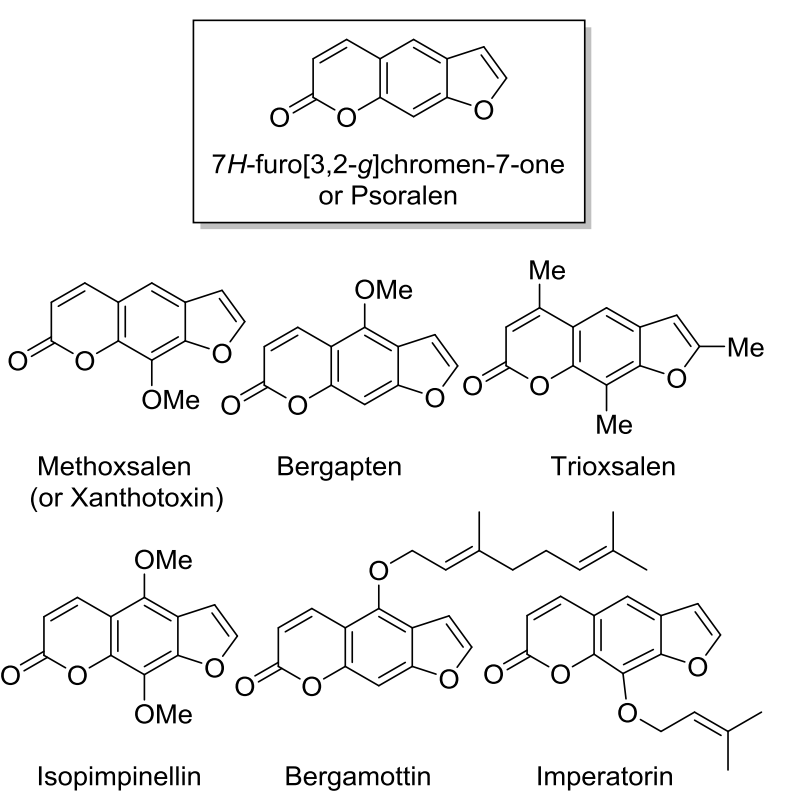

Figure 1. Representative examples of bioactive $7 H$-furo[3,2g]chromen-7-ones.

The first example of Pd-catalyzed direct arylation of benzofuran was reported by Ohta and co-workers who obtained 2-phenylbenzofuran from benzofuran and bromobenzene in a low $23 \%$ yield using $\mathrm{Pd}\left(\mathrm{PPh}_{3}\right)_{4}$ as the catalyst (Scheme 1, a). ${ }^{1}$ Fagnou

\footnotetext{
* Corresponding author. Tel.: +33 (0)2 232332 06; e-mail: jean-francois.soule@univ-rennes1.fr

* Corresponding author. Tel.: +33 (0)2 232363 84; e-mail: henri.doucet@univ-rennes1.fr
} 
an via the coupling of benzofuran with 2-bromotoluene using 2 $\mathrm{mol} \% \mathrm{Pd}(\mathrm{OAc})_{2}$ and $4 \mathrm{~mol}_{\%} \mathrm{PCy}_{3}$ as the catalyst (Scheme 1, b). ${ }^{3 \mathrm{a}}$

a)

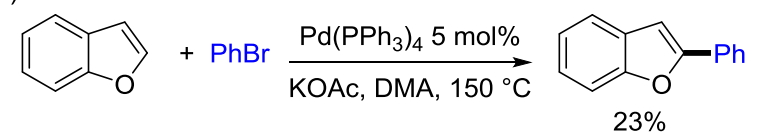

b)

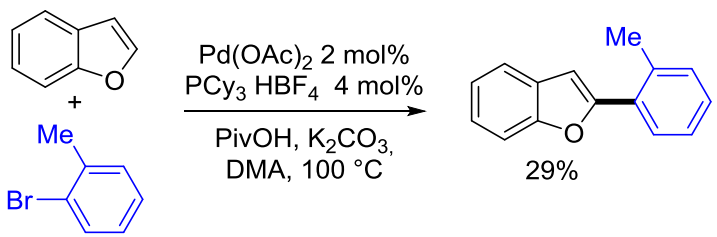

Scheme 1. Pd-catalyzed direct arylations of benzofuran with aryl bromides.

The C2-arylation of benzofurans using aryl halides as the aryl source proceeds via a concerted metallation deprotonation (CMD) mechanism. ${ }^{4}$ According to Gorelsky calculations, in the CMD process, the $\mathrm{C} 2$ carbon of benzofuran should be slightly more reactive than the $\mathrm{C} 3$ carbon (energies: 26.3 vs 27.5) (Fig. S1). ${ }^{4}$ This minor difference in the energy of activation explains the poor regioselectivity, and therefore the poor yields observed for the Pd-catalyzed arylations of benzofuran with aryl bromides, as mixtures of C2- and C3-arylated and also C2,C3-diarylated benzofurans are obtained (Scheme 1, a left). ${ }^{3}$

In 2009, Dong and co-workers described the Pd-catalyzed desulfitative coupling of a quinoline derivative using benzenesulfonyl chlorides as the aryl source in the presence of $\mathrm{Ag}_{2} \mathrm{CO}_{3}$ and $\mathrm{CuBr}$. Subsequently, the use of benzenesulfonyl chlorides ${ }^{5}$ for the Pd-catalyzed direct arylation has been extended to other heteroarenes by several groups. ${ }^{6}$ Our group reported that the use of benzenesulfonyl chlorides as the coupling partner instead of aryl halides allows control of the regioselectivity of the palladium-catalyzed arylation of benzofurans in favor of the $\mathrm{C} 2$ carbon (Scheme 2, a right). ${ }^{7}$ The first step of the catalytic cycle with benzenesulfonyl chlorides is presumably oxidative addition of the benzenesulfonyl chloride to $\mathrm{Pd}(\mathrm{II})$ to afford a $\mathrm{Pd}(\mathrm{IV})$ intermediate instead of the $\mathrm{Pd}(0) / \mathrm{Pd}(\mathrm{II})$ catalytic cycle for the reactions using aryl halides. ${ }^{8}$ It should also be noted that the Pdcatalyzed direct C2-arylation of benzofuran using other aryl sources such as aryldiazonium salts or arylboronic acids, ${ }^{9}$ or under oxidative coupling conditions, ${ }^{10}$ has also been described. In addition, the Pd-catalyzed C4-arylation of coumarins has been reported (Scheme $2, \mathrm{~b}){ }^{11}$<smiles>c1ccc(-c2cc3ccccc3o2)cc1</smiles>

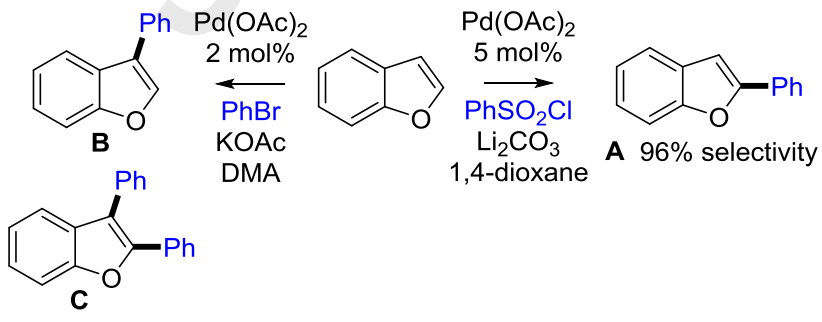

Ratio A:B:C 50:17:33

b)
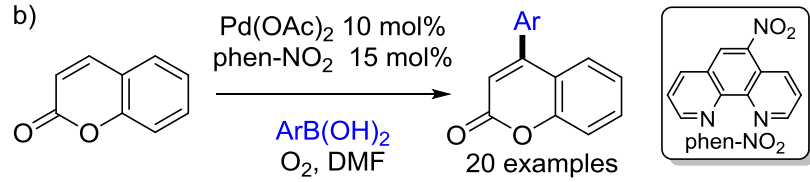

Scheme 2. Influence of the aryl source on the regioselectivity of the Pd-catalyzed direct arylation of benzofuran and arylation of coumarin. $^{7 \mathrm{a}, 11}$

To the best of our knowledge, the Pd-catalyzed direct arylation methodology has not been applied to the synthesis of 2arylated Psoralenes. ${ }^{12}$ Herein, we describe reaction conditions allowing the regioselective direct $\mathrm{C} 2$-arylation or $\mathrm{C} 2, \mathrm{C} 3$ diarylation of Methoxalen using readily available catalysts, bases and substrates. The influence of the substituents on the aryl source is also reported.

\section{Results and Discussion}

Based on our previous results on palladium-catalyzed desulfitative coupling with benzofuran, ${ }^{7 \mathrm{a}}$ we first examined the regioselectivity of the arylation of Methoxalen with 1.5 equiv. of 4-(trifluoromethyl)benzenesulfonyl chloride (Scheme 3). In the presence of $5 \mathrm{~mol} \% \mathrm{Pd}(\mathrm{OAc})_{2}$ and $\mathrm{Li}_{2} \mathrm{CO}_{3}$ at $140{ }^{\circ} \mathrm{C}$ in $1,4-$ dioxane, the desired C2-arylated Methoxalen 1a was regioselectively obtained in $55 \%$ yield. ${ }^{13,14}$ The structure of 1a was confirmed by single crystal X-ray analysis. ${ }^{15}$ Under these conditions, no formation of $\mathrm{C} 3$-arylated Methoxalen $\mathbf{1 b}$ or C2,C3-diarylation product 1c was detected by GC/MS analysis of the crude mixture; a significant amount of degradation products was also observed. Moreover, no arylation on the pyran-2-one ring to produce compound 1d was observed. Conversely, as expected, the use of 1.5 equiv. of 4(trifluoromethyl)bromobenzene as the aryl source, using $2 \mathrm{~mol} \%$ $\mathrm{Pd}(\mathrm{OAc})_{2}$ and KOAc in DMA, afforded a mixture of the C2- and C3-arylated Methoxalens $\mathbf{1 a}$ and $\mathbf{1 b}$ and also a significant amount of C2,C3-diarylated Methoxalen 1c which could not be separated by column chromatography on silica gel.

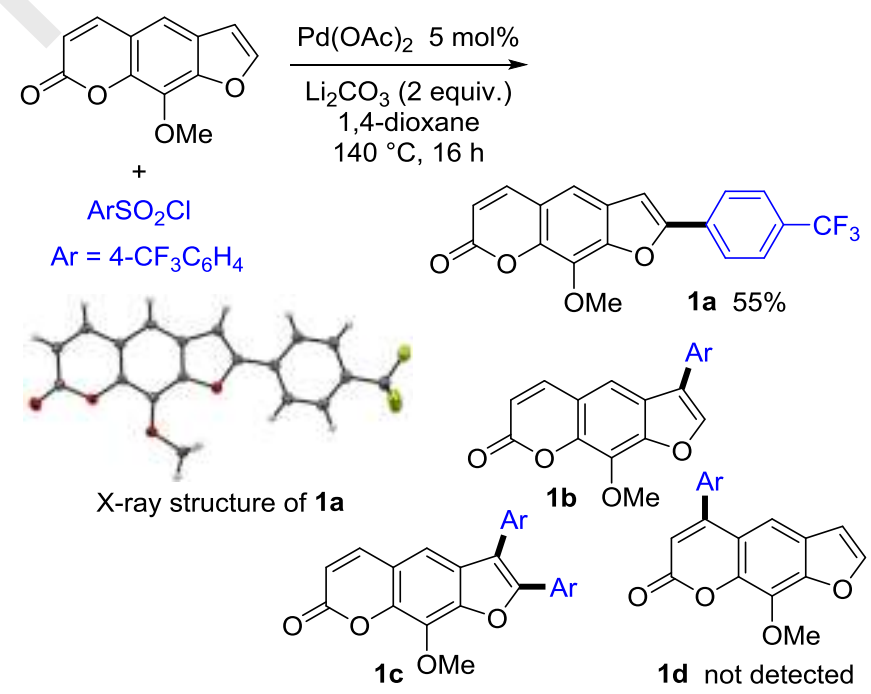

With 4- $\mathrm{CF}_{3} \mathrm{C}_{6} \mathrm{H}_{4} \mathrm{Br}$ instead of $4-\mathrm{CF}_{3} \mathrm{C}_{6} \mathrm{H}_{4} \mathrm{SO}_{2} \mathrm{Cl}$ as the aryl source, using $2 \mathrm{~mol} \% \mathrm{Pd}(\mathrm{OAc})_{2}$, $\mathrm{KOAc}\left(2\right.$ equiv.), DMA, $150^{\circ} \mathrm{C}, 16 \mathrm{~h}$, a mixture of $\mathbf{1 a}, \mathbf{1 b}$ and $1 \mathrm{c}$ was obtained.

Scheme 3. Regioselectivity of the Pd-catalyzed direct arylations of Methoxalen with a benzenesulfonyl chloride.

Then, the influence of the substituents on the benzenesulfonyl chlorides for the $\mathrm{C} 2$-arylation of Methoxalen was studied using 5 $\mathrm{mol} \% \mathrm{Pd}(\mathrm{OAc})_{2}$ and $\mathrm{Li}_{2} \mathrm{CO}_{3}$ in 1,4-dioxane at $140{ }^{\circ} \mathrm{C}$ (Scheme 4). We initially employed electron-deficient benzenesulfonyl chlorides. A cyano substituent at the C4-position of the benzenesulfonyl chloride gave product 2 in a low yield; whereas, 4-chlorobenzenesulfonyl chloride afforded the C2-arylated Methoxalen 3 in 51\% yield. From the slightly electron-deficient 
4-flı

obtained for 4 . The electron-neutral benzenesulfonyl chloride and slightly electron-rich 4-tert-butylbenzenesulfonyl chloride gave the desired coupling products 5 and $\mathbf{6}$ in $52 \%$ and 54\% yield, respectively. With these substrates, the formation of unidentified degradation products was also observed. On the other hand, the use of more electron-rich 4-methoxybenzenesulfonyl chloride led to the C2-arylated Methoxalen 7 in only $27 \%$ yield, due to poor conversion. We also studied the influence of meta-substituents on the benzenesulfonyl derivative. With a chloro-substituted benzene derivative, a moderate yield (48\%) was obtained for $\mathbf{8}$; whereas 3-(trifluoromethyl)benzenesulfonyl chloride gave 9 in $71 \%$ yield. From 3,5-bis(trifluoromethyl)benzenesulfonyl chloride, the expected product $\mathbf{1 0}$ was formed in $45 \%$ yield.

As the use of benzenesulfonyl chlorides as the coupling partners in Pd-catalyzed direct arylations tolerates both bromoand iodo-substituents, ${ }^{16}$ the behavior of a set of halobenzenesulfonyl chlorides for the C2-arylation of Methoxalen was investigated (Scheme 4). The reaction of 1.5 equiv. of 4-bromobenzenesulfonyl chloride and 1 equiv. of Methoxalen in the presence of $5 \mathrm{~mol} \% \mathrm{Pd}(\mathrm{OAc})_{2}$ regioselectively gave the C2 arylated Methoxalen $\mathbf{1 1}$ in 38\% yield without cleavage of the $\mathrm{C}$-Br bond of 4-bromobenzenesulfonyl chloride. In the course of this reaction, no formation of the 1,4-diarylated benzene derivative from both $\mathrm{C}-\mathrm{SO}_{2} \mathrm{Cl}$ and $\mathrm{C}-\mathrm{Br}$ bonds activation was detected by GC/MS analysis of the crude mixture. The reactivity of 2- and 3-bromobenzenesulfonyl chlorides was also investigated. The target compounds $\mathbf{1 2}$ and $\mathbf{1 3}$ were isolated in $28 \%$ and $21 \%$ yields, respectively, again without cleavage of the $\mathrm{C}-\mathrm{Br}$ bonds. We also examined the reaction of 4iodobenzenesulfonyl chloride with Methoxalen. The reaction afforded the desired product $\mathbf{1 4}$ in only $15 \%$ yield due to the formation of unidentified side-products, but without cleavage of the C-I bond, thus allowing further transformations.

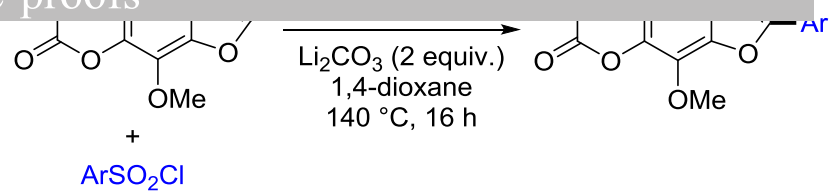<smiles>[R]c1ccc(-c2cc3cc4ccc(=O)oc4c(OC)c3o2)cc1</smiles>

$\mathrm{R} \quad$ Yield (\%)

$\mathrm{CN} \quad 2 \quad 16$

$\mathrm{Cl} \quad 3 \quad 51$

F 448

H $\quad 5 \quad 52$

$\begin{array}{lll}\mathrm{B} u & 6 & 54\end{array}$

OMe $7 \quad 27$<smiles></smiles>

$\mathrm{Cl} \quad 8 \quad 48$

$\begin{array}{lll}\mathrm{CF}_{3} & 9 & 71\end{array}$

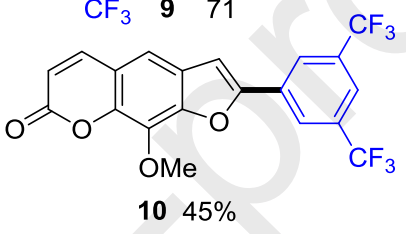<smiles>COc1c2oc(-c3ccc(Br)cc3)cc2cc2ccc(=O)oc12</smiles>

$1138 \%$<smiles>COc1c2oc(-c3cccc(Br)c3)cc2cc2ccc(=O)oc12</smiles>

$1228 \%$

$1321 \%$

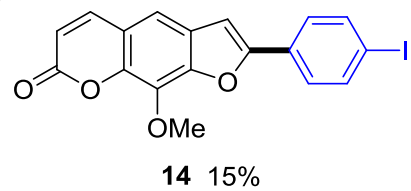

$1415 \%$<smiles>COc1c2oc(-c3ccccc3Br)cc2cc2ccc(=O)oc12</smiles>

Scheme 4. Pd-catalyzed direct C2-arylations of Methoxalen using benzenesulfonyl chlorides.

Finally, as both the C2- and C3-positions of Methoxalen had been found to be reactive for direct arylations with 4(trifluoromethyl)bromobenzene using $\mathrm{Pd}(\mathrm{OAc})_{2}$ and $\mathrm{KOAc}$ in DMA (see Scheme 3), the reactivity of Methoxalen was studied in the one pot C2,C3-diarylation by aryl bromides (Scheme 5). Methoxalen was reacted with 3 equiv. of 4-bromochlorobenzene or 4-(trifluoromethyl)bromobenzene in the presence of $2 \mathrm{~mol} \%$ $\mathrm{PdCl}\left(\mathrm{C}_{3} \mathrm{H}_{5}\right)(\mathrm{dppb})^{17}$ and KOAc in DMA; these conditions were previously found to be effective for the diarylation of benzofuran. ${ }^{18}$ The desired C2,C3-diarylated products $\mathbf{1 5}$ and 1c were obtained in $60 \%$ and $74 \%$ yield, respectively. ${ }^{19,20}$

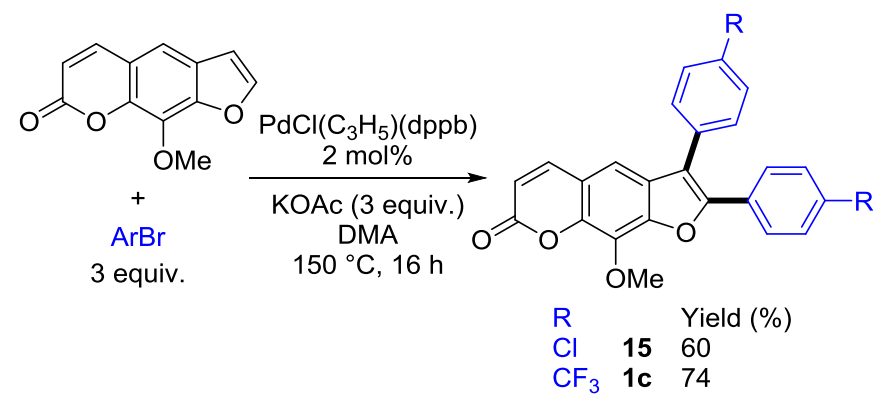

Scheme 5. Pd-catalyzed direct C2,C3-diarylations of Methoxalen using aryl bromides.

In summary, we report herein the first examples of metalcatalyzed $\mathrm{C}-\mathrm{H}$ bond functionalizations of Methoxalen and the first methods allowing the preparation of C2-arylated or C2,C3diarylated Methoxalen derivatives. Low to moderate yields for C2-arylated Methoxalen were obtained using benzenesulfonyl chlorides as the aryl source; whereas, using an excess of aryl bromides the C2,C3-diarylated Methoxalen were produced in good yields. These couplings tolerated a variety of substituents on the benzenesulfonyl chlorides and aryl bromides. Therefore, 
employs commercially available reactants, catalysts and bases, provides a straightforward access to Methoxalen derivatives allowing to tune or modify their biological properties.

\section{Acknowledgments} HL.

We thank the China Scholarship Council for a fellowship to

\section{References and notes}

1. a) Ohta, A.; Akita, Y.; Ohkuwa, T.; Chiba, M.; Fukunaga, R.; Miyafuji, A.; Nakata, T.; Tani, N.; Aoyagi, Y. Heterocycles 1990, 31, 1951-1958.

2. a) Li, B.-J.; Yang, S.-D.; Shi, Z.-J. Synlett 2008, 949-957; b) Bellina, F.; Rossi, R. Tetrahedron 2009, 65, 10269-10310; c) Ackermann, L.; Vincente, R.; Kapdi, A. R. Angew. Chem. Int. Ed. 2009, 48, 9792-9826; d) Ackermann, L. Chem. Rev. 2011, 111, 1315-1345; e) Kuhl, N.; Hopkinson, M. N.; Wencel-Delord, J.; Glorius, F. Angew. Chem. Int. Ed. 2012, 51, 10236-10254; f) Rossi, R.; Bellina, F.; Lessi, M.; Manzini, C. Adv. Synth. Catal. 2014, 356, 17-117; g) h) Gensch, T.; James, M. J.; Dalton, T.; Glorius, F. Angew. Chem. Int. Ed. 2018, 57, 2296-2306; h) S. Mao, H. Li, X. Shi, J.-F. Soulé, H. Doucet, ChemCatChem, 2019 11, 269-286; i) W. Hagui, H. Doucet, J.-F. Soulé, Chem 2019, 5, 2006-2078.

3. a) Liégault, B.; Petrov, I.; Gorelsky, S. I.; Fagnou, K. J. Org. Chem. 2010, 75, 1047-1060; b) Nandurkar, N. S.; Bhanushali, M. J.; Bhor, M. D.; Bhanage, B. M. Tetrahedron Lett. 2008, 49 , 1045-1048; c) Matsuda, S.; Takahashi, M.; Monguchi, D.; Mori, A. Synlett 2009, 1941-1944.

4. Gorelsky, S. I. Coord. Chem. Rev. 2013, 257, 153-164.

5. a) Zhao, X.; Dimitrijevic, E.; Dong, V. M. J. Am. Chem. Soc. 2009, 131, 3466-3467; b) Zhao, X.; Dong, V. M. Angew. Chem., Int. Ed. 2011, 50, 932-934; For a review on transition-metal mediated C-S bond activation: c) Wang, L.; He, W.; Yu, Z. Chem. Soc. Rev. 2013, 42, 599-621.

6. Yuan, K.; Soulé, J.-F.; Doucet, H. ACS Catal. 2015, 5, 978-991.

7. For the Pd-catalyzed regioselective direct C2-arylation of benzofuran with benzenesulfonyl chlorides: a) Loukotova, L.; Yuan, K.; Doucet, H. ChemCatChem 2014, 6, 1303-1309; b) Hfaiedh, A.; Yuan, K.; Ben Ammar, H.; Ben Hassine, B.; Soulé, J.-F.; Doucet, H. ChemSusChem 2015, 8, 1794-1804

8. Yuan, K.; Doucet, H. Chem. Sci., 2014, 5, 392-396.

9. For intermolecular palladium-catalyzed couplings with arylboron derivatives, aryldiazoniums salts, aryliodonium salts or $N^{\prime}$-acyl arylhydrazines: a) Colas, C.; Goeldner, M. Eur. J. Org. Chem. 1999, 1357-1366; b) Yang, S.-D.; Sun, C.-L.; Fang, Z.; Li, B.-J.; Li, Y.-Z.; Shi, Z.-J. Angew. Chem., Int. Ed. 2008, 47, 1473-1476; c) Wang, Z.i; Li, Y.; Yan, B.; Huang, M.; Wu, Y. Synlett 2015, 26, 531-536; d) Vasquez-Cespedes, S.; Chepiga, K. M.; Moeller, N.; Schaefer, A. H.; Glorius, F. ACS Catal. 2016, 6, 5954-5961; e) Gemoets, H. P. L.; Kalvet, I.; Nyuchev, A. V.; Erdmann, N.; Hessel, V.; Schoenebeck, F.; Noel, T. Chem. Sci. 2017, 8, 10461055; f) Cao, J.; Chen, Z.-L.; Li, S.-M.; Zhu, G.-F.; Yang, Y.-Y.; Wang, C.; Chen, W.-Z.; Wang, J.-T.; Zhang, J.-Q.; Tang, L. Eur. J. Org. Chem. 2018, 2774-2779.

10. For intermolecular palladium-catalyzed oxidative arylations of benzofurans: a) Dwight, T. A.; Rue, N. R.; Charyk, D.; Josselyn, R.; DeBoef, B. Org. Lett. 2007, 9, 3137-3139; b) He, C.-Y.; Fan, S.; Zhang, X. J. Am. Chem. Soc. 2010, 132, 12850-12852; c) Pereira, K. C.; Porter, A. L.; Potavathri, S.; LeBris, A. P.; DeBoef, B. Tetrahedron 2013, 69, 4429-4435.

11. a) Li, Y.; Qi, Z.; Wang, H.; Fu, X.; Duan, C. J. Org. Chem. 2012 77, 2053-2057; b) Khoobi, M.; Alipour, M.; Zarei, S.; Jafarpour, F.; Shafiee, A. Chem. Commun. 2012, 48, 2985-2987.c) Min, M.; Hong, S. Chem. Commun. 2012, 48, 9613-9615.

12. For the synthesis of 2-arylpsoralenes via intramolecular hydroarylation of 6-benzofuranyl alkynoates or oxidative annulation of phenols: a) Kitamura, T.; Otsubo, K. Heterocycles 2012, 86, 759-766; b) Kuram, M. R.; Bhanuchandra, M.; Sahoo, A. K. Angew. Chem. Int. Ed. 2013, 52, 4607-4612.

13. Synthesis of C2-arylated Methoxalens (Scheme 1): To a $25 \mathrm{~mL}$ oven dried Schlenk tube, benzenesulfonyl chloride $(1.5 \mathrm{mmol})$, Methoxalen (0.216 g, $1 \mathrm{mmol}), \mathrm{Li}_{2} \mathrm{CO}_{3}(0.148 \mathrm{~g}, 2 \mathrm{mmol}), 1,4$ vacuum-argon cycles (5 times) and stirred at $140{ }^{\circ} \mathrm{C}$ (oil bath temperature) for 16 hours. After cooling the reaction to room temperature and concentration, the crude mixture was purified by silica column chromatography to afford the C2-arylated Methoxalen.

14. 9-Methoxy-2-(4-(trifluoromethyl)phenyl)-7H-furo[3,2- $g$ ]chromen7-one 1a: Following the procedure of ref 13, 4(trifluoromethyl)benzenesulfonyl chloride (0.367 g, $1.5 \mathrm{mmol})$ and Methoxalen $(0.216 \mathrm{~g}, 1 \mathrm{mmol})$, affords $\mathbf{1 a}$ in $55 \%(0.198 \mathrm{~g})$ yield. ${ }^{1} \mathrm{H}$ NMR (400 MHz, $\left.\mathrm{CDCl}_{3}\right): \delta 7.97(\mathrm{~d}, J=8.1 \mathrm{~Hz}, 2 \mathrm{H})$, $7.77(\mathrm{~d}, J=9.6 \mathrm{~Hz}, 1 \mathrm{H}), 7.73(\mathrm{~d}, J=8.1 \mathrm{~Hz}, 2 \mathrm{H}), 7.37(\mathrm{~s}, 1 \mathrm{H})$, $7.16(\mathrm{~s}, 1 \mathrm{H}), 6.40(\mathrm{~d}, J=9.6 \mathrm{~Hz}, 1 \mathrm{H}), 4.37(\mathrm{~s}, 3 \mathrm{H}) .{ }^{13} \mathrm{C} \mathrm{NMR}(100$ $\left.\mathrm{MHz}, \mathrm{CDCl}_{3}\right): \delta 160.4,156.3,147.9,144.3,143.8,132.8,131.0$ $(\mathrm{q}, J=32.7 \mathrm{~Hz}), 127.5,126.1(\mathrm{q}, J=3.8 \mathrm{~Hz}), 125.3,124.0(\mathrm{q}, J=$ $273.0 \mathrm{~Hz}), 117.1,115.2,113.1,103.1,63.6$. elemental analysis: calcd $(\%)$ for $\mathrm{C}_{19} \mathrm{H}_{11} \mathrm{~F}_{3} \mathrm{O}_{4}$ (360.29): $\mathrm{C}$ 63.34, $\mathrm{H}$ 3.08; found: $\mathrm{C}$ 63.54, H 3.01.

15. X-ray structure of 1: CCDC-1921094.

16. Li, H.; Sasmal, A.; Shi, X.; Soulé, J.-F.; Doucet, H. Org. Biomol. Chem. 2018, 4399-4423.

17. Cantat, T.; Génin, E.; Giroud, C.; Meyer, G.; Jutand, A. J. Organomet. Chem. 2003, 687, 365-376.

18. For Pd-catalyzed direct C2,C3-diarylation of benzofuran: Si Larbi, K.; Djebbar, S.; Soulé, J.-F.; Doucet, H. J. Organomet. Chem. 2017, 843, 32-39.

19. Synthesis of C2,C3-diarylated Methoxalens (Scheme 2): To a 25 $\mathrm{mL}$ oven dried Schlenk tube, aryl bromide ( $3 \mathrm{mmol})$, Methoxalen (1 mmol), KOAc $(0.294 \mathrm{~g}, 3 \mathrm{mmol})$, DMA $(2 \mathrm{~mL})$ and $\mathrm{PdCl}\left(\mathrm{C}_{3} \mathrm{H}_{5}\right)(\mathrm{dppb})(13.6 \mathrm{mg}, 0.02 \mathrm{mmol})$ were successively added. The reaction mixture was evacuated by vacuum-argon cycles $(5$ times) and stirred at $150{ }^{\circ} \mathrm{C}$ (oil bath temperature) for 16 hours. After cooling the reaction to room temperature and concentration, the crude mixture was purified by silica column chromatography to afford the C2,C3-diarylated Methoxalen.

$20.2,3$-Bis(4-chlorophenyl)-9-methoxy-7H-furo[3,2- $g$ ]chromen-7-one 15: Following the procedure of ref 19, 4-bromochlorobenzene $(0.573 \mathrm{~g}, 3 \mathrm{mmol})$ and Methoxalen $(0.216 \mathrm{~g}, 1 \mathrm{mmol})$, affords $\mathbf{1 5}$ in $60 \%(0.262 \mathrm{~g})$ yield. ${ }^{1} \mathrm{H}$ NMR $\left(400 \mathrm{MHz}, \mathrm{CDCl}_{3}\right): \delta 7.70(\mathrm{~d}, J$ $=9.6 \mathrm{~Hz}, 1 \mathrm{H}), 7.57(\mathrm{~d}, J=8.4 \mathrm{~Hz}, 2 \mathrm{H}), 7.50(\mathrm{~d}, J=8.4 \mathrm{~Hz}, 2 \mathrm{H})$, $7.41(\mathrm{~d}, J=8.4 \mathrm{~Hz}, 2 \mathrm{H}), 7.33(\mathrm{~d}, J=8.4 \mathrm{~Hz}, 2 \mathrm{H}), 7.16(\mathrm{~s}, 1 \mathrm{H})$, $6.37(\mathrm{~d}, J=9.6 \mathrm{~Hz}, 1 \mathrm{H}), 4.37(\mathrm{~s}, 3 \mathrm{H}) .{ }^{13} \mathrm{C}$ NMR $(100 \mathrm{MHz}$, $\left.\mathrm{CDCl}_{3}\right): \delta 160.4,151.5,146.8,144.2,143.8,135.4,134.6,132.7$, $131.0,130.0,129.9,129.2,128.8,128.3,128.0,117.0,116.6$, 115.2, 111.7, 61.6. elemental analysis: calcd (\%) for $\mathrm{C}_{24} \mathrm{H}_{14} \mathrm{Cl}_{2} \mathrm{O}_{4}$ (437.27): C 65.92, H 3.23; found: C 65.99, H 3.08.

\section{Supplementary Material}

Experimental procedures, product characterization and copies of the ${ }^{1} \mathrm{H}$ and ${ }^{13} \mathrm{C}$ NMR for all compounds.

\section{Click here to remove instruction text}


Highlights

- First examples of metal-catalyzed C-H bond functionalizations of Methoxalen.

- One pot access to C2-arylated or C2,C3diarylated Methoxalen derivatives.

- A variety of substituents on the benzenesulfonyl chlorides and aryl bromides tolerated.

- Commercially available reactants, catalysts and bases. 